\title{
Prevalence of sub-clinical mastitis in dairy farms
}

\author{
MA AL Quaderi, M Husain, MGS Alam, M Khatun* and MA Hossain \\ Department of Surgery and Obstetrics, Faculty of Veterinary Science, Bangladesh \\ Agricultural University, Mymensingh-2202, Bangladesh
}

\begin{abstract}
A total of 560 lactating cows belonging to Bangladesh Agricultural University dairy farm $(\mathrm{n}=59)$ : Local Zebu (L), Local $\times$ Friesian $(\mathrm{L} \times \mathrm{F})$, Local $\times$ Jersey $(\mathrm{L} \times \mathrm{J})$, Local $\times$ Red Chittagong Cattle $(\mathrm{L} \times \mathrm{RCC})$, Local $\times$ Sahiwal $(\mathrm{L} \times \mathrm{SL})$, Red Chittagong Cattle $(\mathrm{RCC})$; and Central Cattle Breeding Station and Dairy Farm $(n=501)$ : Local Zebu, L $\times$ F, SL $\times$ F, Sahiwal and Australian Friesian Sahiwal (AFS) were selected to measure prevalence of subclinical mastitis (SM). The California Mastitis Test was done and the prevalence of SM was $68 \%$ on cow basis and $57 \%$ on quarter basis. The prevalence rate was significantly higher in $\mathrm{L} \times \mathrm{F}(87 \%, \mathrm{P}<0.05), \mathrm{SL} \times \mathrm{F}(88 \%, \mathrm{P}<0.05), \mathrm{L} \times \mathrm{J}(100 \%, \mathrm{P}<0.01), \mathrm{AFS}(89 \%, \mathrm{P}<$ $0.05)$ and SL $(100 \%, \mathrm{P}<0.01)$. The local Zebu $(31 \%)$ and RCC $(28 \%)$ were least susceptible to SM. SM was significantly higher in multiparous $(\mathrm{P}<0.05)$ and older cows $(\mathrm{P}<0.05)$. The front quarters were more prone to SM than the rear. Factors such as breed, age, parity and management may have been responsible for high prevalence of SM in both farms. (Bangl. vet. 2013. Vol. 30, No. 2, 70-77)
\end{abstract}

\section{Introduction}

Mastitis is inflammation of the mammary gland (Burvenich et al., 2007; Fox, 2009) characterized by swelling, heat, redness, hardness and pain with abnormalities in milk. It is the most costly disease to the dairy industry, because of decreased milk yield, treatment and prevention cost and finally culling of the affected cows (Bar et al., 2008; Hertl et al., 2011; Murphy et al., 2008). Mastitis compromises animal welfare as well as its treatment is associated with human health hazard (Fogsgaard et al., 2011; Rasmussen et al., 2011).

Mastitis is most commonly caused by the bacteria belongs to Enterobacteria, Staphylococci, Streptococci families (Bradley, 2002). About 75-80\% mastitis is subclinical, characterized by a significantly increased leukocyte count in milk (Bradley 2002). Subclinical mastitis (SM) affects the quality, quantity of milk, damages the udder tissue and most important mastitis form to cause greatest economic loss. SM is silent usually of long duration and often remained undetected in existing poor udder health management system where lack of advisory scheme. Hence, early detection and the prevalence records of SM are important for mastitis control. Comprehensive reports on SM in Bangladesh are lacking but a prevalence of $47 \%$ was recorded (Kader et al., 2003), and 55\% was recorded in Sahiwal cows (Ghosh et al., 2004). This study was undertaken to study:

*Corresponding author:- E-mail: monarahman24@yahoo.com 
- The prevalence of SM in two intensively managed dairy farms in Bangladesh

- The involvement of breed, parity, and age with the prevalence of SM

- The problems relevant to the prevalence of SM in dairy farms.

\section{Materials and Methods}

\section{Study area}

The investigation was conducted at Bangladesh Agricultural University Dairy farm (BAUDF) and the Central Cattle Breeding Station and Dairy Farm (CCBSDF), Savar, Dhaka from January to May 2005 and June to November 2007. The farms were visited several times to collect breed, parities, ages of cows and the management practices.

\section{Animals, housing, feeding and milking}

The BAUDF consisted of 59 lactating cows: Local Zebu (L), Local $\times$ Friesian $(\mathrm{L} \times \mathrm{F})$, Local $\times$ Jersey $(\mathrm{L} \times \mathrm{J})$, Local $\times$ Red Chittagong Cattle $(\mathrm{L} \times \mathrm{RCC})$, Local $\times$ Sahiwal $(\mathrm{L} \times$ SL), Red Chittagong Cattle (RCC). The CCBSDF consisted of 501 cows: Local Zebu, L $\times$ F, SL $\times$ F, Sahiwal and Australian Friesian Sahiwal (AFS). The average body weights of the local and crossbred cows were $250 \mathrm{~kg} \pm 15 \mathrm{~kg}$ and $300 \mathrm{~kg} \pm 20 \mathrm{~kg}$, respectively. The floor of the houses in both farms was made of bricks and cement. No bedding material was used. Stall feeding was practised in both farms in the morning and afternoon. All the cows had access to water ad libitum. All lactating cows were handmilked in the morning and afternoon with their calf at feet. There was no practice of teat-dipping or dry cow therapy.

\section{Sample collection and detection of subclinical mastitis}

Fresh milk samples from each quarter of selected cows were collected aseptically in separate glass tube as described by Rosenberger (1979) at morning milking and the tube was labelled with the number of the cow. California mastitis test (CMT) was used to detect sub-clinical mastitis (SM) using the CMT test liquid and a plastic paddle with four cups according to the manual (KRUUSE ${ }^{\circledR}$ company of Denmark). The initial milk was discarded and a small amount of milk was squeezed out of each teat into the paddle. The surplus milk was tipped out of the paddle leaving $2 \mathrm{~mL}$ of milk in each cup. Then $3 \mathrm{~mL}$ of CMT test liquid was added to each cup. The paddle was gently rotated to thoroughly mix the contents. The reaction was scored as follows:

Negative (1): The mixture remained unchanged; Weak positive (2): The mixture began to coagulate and turned slightly mucus but could still be shaken; Positive (3): Movement of the mixture and unmistakable mucus formation was observed and it was still possible to tip a small portion of the mixture cut; Very positive (4): A jellylike mucus consistency was formed, it was difficult to shake the mixture and it was no longer possible to tip any surplus mixture out. 


\section{Statistical analysis}

Data were entered into Microsoft Excel ${ }^{\circledR}$ work sheets. Prevalence was defined as the number of positive cases of SM per 100 cows tested. T-test was performed to obtain the values of significance using the SPSS ${ }^{\circledR}$ software (Steel and Story, 1983).

\section{Results and Discussion}

Of 560 cows, 386 (68\%) were positive to CMT and of 2059 active quarters, 1167 (57\%) were positive to SM. The CMT graded SM scores were as follows: $43 \%$ as score $2,35 \%$ as score 3 and $22 \%$ as score 4 . The front-left, front-right, rear-left, and rear-right quarter infection rates were $60 \%, 59 \%, 55 \%$ and $52 \%$, respectively. The prevalence of $\mathrm{SM}$ in $\mathrm{L}, \mathrm{L} \times \mathrm{F}, \mathrm{L} \times \mathrm{SL}, \mathrm{SL} \times \mathrm{F}, \mathrm{RCC}, \mathrm{L} \times \mathrm{RCC}, \mathrm{AFS}, \mathrm{L} \times \mathrm{J}$, and SL breeds were $31 \%$, $87 \%, 56 \%, 88 \%, 28 \%, 50 \%, 89 \%, 100 \%$ and $100 \%$, respectively (Table 1 ). The prevalence was significantly higher in $\mathrm{L} \times \mathrm{F}(\mathrm{P}<0.05), \mathrm{SL} \times \mathrm{F}(\mathrm{P}<0.05), \mathrm{ASF}(\mathrm{P}<0.05), \mathrm{SL}(\mathrm{P}<$ $0.01)$ and $\mathrm{L} \times \mathrm{J}(\mathrm{P}<0.01)$.

Table 1. Prevalence of California Mastitis Test (CMT)-positive cases in different breeds

\begin{tabular}{c|cccc}
\hline Breeds & No. of tested cows & No. of CMT $(+)$ cows & \% of CMT (+) cows \\
\hline Local & 134 & $41 \mathrm{~b}$ & $30.6 \mathrm{~b}$ \\
$\mathrm{~L} \times \mathrm{F}$ & 243 & $210 \mathrm{a}$ & $86.7 \mathrm{a}$ \\
$\mathrm{L} \times \mathrm{SL}$ & 48 & $27 \mathrm{c}$ & $56.3 \mathrm{c}$ \\
$\mathrm{SL} \times \mathrm{F}$ & 89 & $78 \mathrm{a}$ & $87.6 \mathrm{a}$ \\
RCC & 18 & $5 \mathrm{~b}$ & $27.8 \mathrm{~b}$ \\
$\mathrm{~L} \times \mathrm{RCC}$ & 4 & $2 \mathrm{~d}$ & $50.0 \mathrm{~d}$ \\
ASF & 9 & $8 \mathrm{~d}$ & $88.9 \mathrm{~d}$ \\
L $\times \mathrm{J}$ & 6 & $6 \mathrm{~d}$ & $100 \mathrm{~d}$ \\
SL & 9 & $9 \mathrm{~d}$ & $100 \mathrm{~d}$ \\
Total & 560 & 386 & $*$ \\
Level of significance & & $*$ & $*$
\end{tabular}

ASF $=$ Australian Sahiwal Friesian, F = Friesian, $\mathrm{J}=$ Jersey, $\mathrm{L}=$ Local Zebu, $\mathrm{SL}=$ Sahiwal, RCC $=$ Red Chittagong Cattle. ${ }^{*}$ Within columns figures with different letters differ significantly $(\mathrm{P}<0.05)$

The prevalence of SM in cows from $1^{\text {st }}$ to $7^{\text {th }}$ parity is presented in Fig. 1. The prevalence of SM was $76.4 \%, 82.5 \%, 71.7 \%, 92.3 \%, 88.0 \%, 86.4 \%$ and $92.3 \%$ in parities 1 to 7 , respectively. The prevalence was significantly $(\mathrm{P}<0.05)$ higher in parity $4^{\text {th }}$ and above.

The prevalence of SM in cows aged 2 to 14 years was $50 \%, 69.8 \%, 64 \%, 68.8 \%, 68.5 \%$, $65.6 \%, 59.6 \%, 62.8 \%, 71.1 \%, 75.7 \%, 65.2 \%, 66.7 \%, 88.6 \%$, respectively. Cows aged 14 years and above had significantly higher $(\mathrm{P}<0.05)$ prevalence of SM (Fig. 2). 


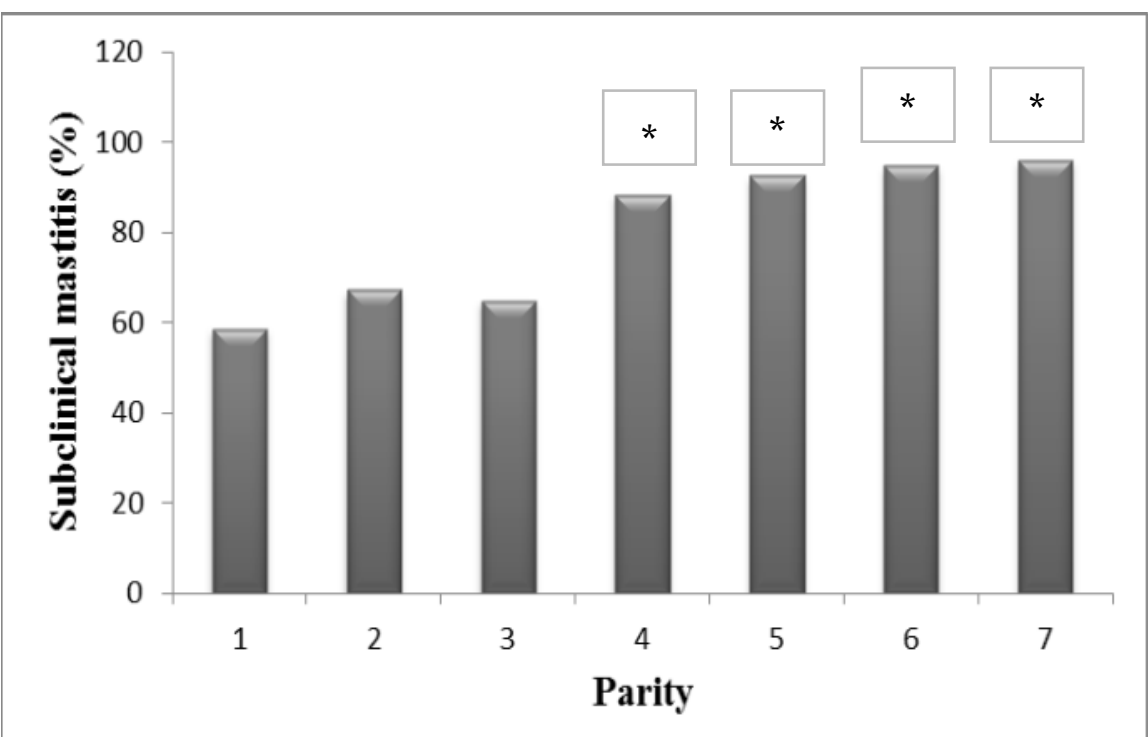

Fig. 1. The prevalence of sub-clinical mastitis in different parities, ${ }^{*}$ Means $\mathrm{P}<0.05$

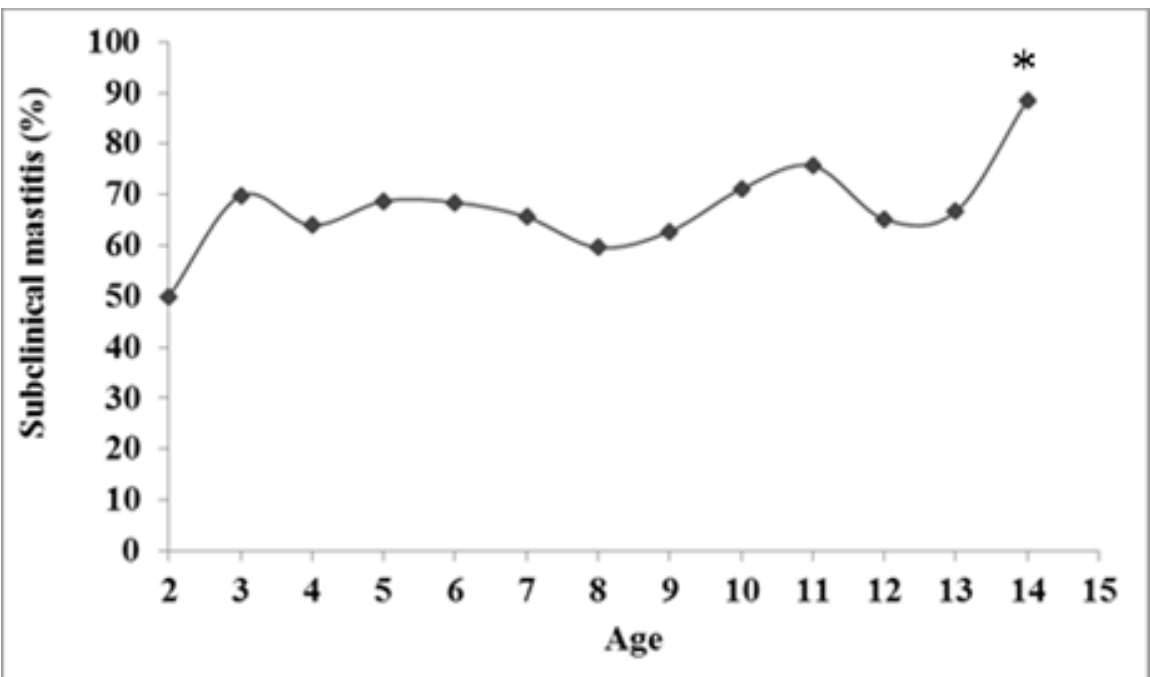

Fig. 2. The prevalence of sub-clinical mastitis in cows of different ages, *Means $\mathrm{P}<0.05$

\section{Management}

Management in BAUDF and the CCBSDF was poor. There was no post-milking teatdipping, no udder towels were used, and there was no dry cow therapy. The milkers did not wash their hands between milking of cows. The cows were washed twice daily with fresh water, but cow dung was sticking to the teats and udder during milking.

Housing was poor. Spiders' webs were seen in the beams. In both the farms, manure was removed only twice daily and the cows had to lie on the manured floor. No 
disinfectant was regularly used to disinfect the floor. The floors were not regularly washed and were embedded with algae.

Combined effect of breed, age, parity and management were responsible for high prevalence of SM in both BAUDF and CCBSDF. The prevalence of SM was significantly higher in $\mathrm{L} \times \mathrm{F}, \mathrm{SL} \times \mathrm{F}, \mathrm{L} \times \mathrm{J}, \mathrm{AFS}$ crosses and in SL breed. The $\mathrm{L}$ and RCC were least susceptible to SM. Older (over 14 years) and higher parity cows (Over 4) had significantly higher prevalence of SM.

Management of the herd and hygienic milking are considered important risk factors for SM (Kivaria et al., 2004; Sarkar et al., 2013). The management and hygienic conditions of the farms were poor, which might lead to higher susceptibility to SM. Despite these L, RCC, L $\times$ RCC, L $\times$ SL were less susceptible to SM with least susceptibility of pure L and RCC cows. Our study supports Kader et al. (2003); Hossoin (2004) measured the prevalence of SM in L as $45.5 \%$ \& $25 \%$, respectively, compared with our finding of $31 \%$. However, difference in the prevalence might be due to seasonal and management variations, number of animals observed. In contrast, higher prevalence was recorded in $\mathrm{L} \times \mathrm{F}, \mathrm{SL} \times \mathrm{F}, \mathrm{AFS}$, which is important for culling (Bell et al., 2010). It would be interesting to investigate the reasons for higher resistance of L, RCC and less resistance of Holstein-Friesian cows. Genomic influence studies on mastitis are emerging (He et al., 2011; Pighetti et al., 2011; Khatun et al., 2013). Somatic cell count (SCC) has significant genetic association for SM either in challenged E. coli mastitis (Khatun et al., 2013) or whole genome study (Minozzi et al., 2011). Hence, our local zebu and zebu cross can be investigated in regard to SCC level for SM, which would be the basis for further genomic study. However, number of total cows for $\mathrm{L} \times \mathrm{RCC}, \mathrm{L} \times \mathrm{J}, \mathrm{ASF}$ and SL were less, which should be increased in future to get more significant result.

The increase in SM with age is consistent with other studies (Kader et al., 2003; Ghosh et al., 2004; Radostits et al., 2000). The fluctuation might be due to variation in the number of cows in different age groups (Fig. 2). Increased age predisposes the cow to exposure of infection with mastitis pathogens and decreases the potency of the teat sphincter (Pankey et al., 1991). In contrast younger cows possess significantly better polymorphonuclear leukocyte function than multiparous cows (Dulin et al., 1988; Hogan et al., 1989). SM increases with parity (Kader et al., 2003; Mungube et al, 2004; Nooruddin et al., 1997; Sarkar et al., 2013). Our study found same findings where cows in $4^{\text {th }}$ parity and above had significantly higher prevalence of SM than other parities. The mean prevalence of SM in cows $(68 \%)$ is higher than Ghosh et al. (2004; 55\%); Gianneechini et al. (2002; 52\%). The quarter prevalence $(57 \%)$ was close to Kader et al. (2003; 46.6\%); Jin et al. (2000; 55.5\%). The differences might be due to hygienic practice, number of cows observed and season.

Post-milking teat dipping (Erskine and Eberhart, 1990), milker preparation and dry cow therapy reduce the prevalence of SM (Shem et al., 2001; Kivaria et al., 2004; Sarkar et al., 2013), but were not practised in the farms. Moreover lack of routine detection of SM (Busato et al., 2000), large herd size (Kivaria et al., 2004; Romain et al., 2000), water 
scarcity, residual suckling, dirty floor embedded with algae, delay in manure removal, no use of disinfectant may have aggravated the condition. Poor management and compromised animal welfare affect the productivity of farms (Costa et al., 2013; Husfeldt et al., 2012). Good management (Sarkar et al., 2013), herbal therapy (Fang et al., 1993), dry-cow therapy and teat dipping can markedly reduce the incidence of SM.

In conclusion, the prevalence of SM was significantly higher in $\mathrm{L} \times \mathrm{F}, \mathrm{SL} \times \mathrm{F}, \mathrm{L} \times \mathrm{J}$, AFS crosses and in SL cows. The L and RCC were least susceptible to SM. Multiparous cows (over $4^{\text {th }}$ parity) and older cows (over 14 years) were significantly more susceptible to SM. Good management might reduce the prevalence of SM in Bangladesh.

\section{References}

Bar D, Tauer LW, Bennett G, Gonzalez RN, Hertl JA, Schukken YH, Schulte HF, Welcome FL, Grohn YT 2008: The cost of generic clinical mastitis in dairy cows as estimated by using dynamic programming. Journal of Dairy Science 91 2205-2214.

Bell MJ, Wall E, Russell G, Roberts DJ, Simm G 2010: Risk factors for culling in HolsteinFriesian dairy cows. Veterinary Record 167 238-240.

Busato A, Trachsel P, Schallibaum M, Blum JW 2000: Udder health and risk factors for subclinical mastitis in organic dairy farms in Switzerland. Preventive Veterinary Medicine 44 205-220.

Burvenich C, Bannerman DD, Lippolis JD, Peelman L, Nonnecke BJ, Kehrli MEJ, Paape MJ 2007: Cumulative physiological events influence the inflammatory response of the bovine udder to Escherichia coli infections during the transition period. Journal of Dairy Science 90 39-54.

Bradley A 2002: Bovine mastitis: an evolving disease. Veterinary Journal 164 116-128.

Costa JH, Hötzel MJ, Longo C, Balcão LF 2013: Survey of management practices that influence production and welfare of dairy cattle on family farms in southern Brazil. Journal of Dairy Science 96 307-317.

Dulin AM, Paape MJ, Nickerson SC 1988: Comparison of phagocytosis and chemiluminescence by blood and mammary gland neutrophils from multiparous and nulliparous cows. American Journal of Veterinary Research 49 172-177.

Erskine RJ, Eberhart RJ 1990: Post milking teat dipping use in low somatic cell count in dairy herds. Journal of Dairy Science 731256.

Fang WH, Jiang CS, Liu HR 1993: Epidemiological aspects of bovine mastitis and its control in several dairy herds in Southeastern China. Preventive Veterinary Medicine 15 169-180.

Fox LK 2009: Prevalence, incidence and risk factors of heifer mastitis. Veterinary Microbiology 134 82- 88.

Fogsgaard KK, Røntved CM, Sørensen P, Herskin MS 2012: Sickness behaviour in dairy cows during Escherichia coli mastitis. Journal of Dairy Science 95 630-638. 
Ghosh CP, Nagpaul PK, Prasad S 2004: Factors affecting sub-clinical mastitis in Sahiwal cows. Indian Journal of Dairy Science 57 127-131.

Gianneechini R, concha C, Rivero R, Delucci I, Moreno LJ 2002: Occurrence of clinical and sub-clinical mastitis in dairy herds in west littoral region in Uruguay. Acta Veterinarian Scandinavica 43 221-230.

He Y, Chu Q, Ma P, Wang Y, Zhang Q, Sun D, Zhang Yi, Yu Y, Zhang Y 2011: Association of bovine CD4 and STAT5b single nucleotide polymorphisms with somatic cell scores and milk production traits in Chinese Holsteins. Journal of Dairy Research 78 242-249.

Hertl JA, Schukken YH, Bar D, Bennett GJ, Gonzalez RN, Rauch BJ, Welcome FL, Tauer LW, Grohn YT 2011: The effect of recurrent episodes of clinical mastitis caused by gram-positive and gram-negative bacteria and other organisms on mortality and culling in Holstein dairy cows. Journal of Dairy Science 94 4863-4877.

Hogan JS, Smith KL, Hoblet KH 1989: Field survey of clinical mastitis in low somatic cell count herds. Journal of Dairy Science 72 1547-1553.

Hossoin SMA 2004: Efficacy of dry cow therapy in mastitis control strategy. MS Thesis. Department of Surgery and Obstetrics, Faculty of Veterinary Science, Bangladesh Agricultural University, Mymensingh.

Husfeldt AW, Endres MI 2012: Association between stall surface and some animal welfare measurements in free stall dairy herds using recycled manure solids for bedding. Journal of Dairy Science 95 5626-5634.

Jin GM, Jiang YL, Yang JS, Gen YB, Zhou J, Wang G 2000: Investigation on the recessive mastitis in dairy cows of Northern Anhui, China. China Dairy Cattle 4 39-40.

Kader MA, Samad MA, Saha S 2003: Influence of host level factors on the prevalence and economics of subclinical mastitis in dairy cows in Bangladesh. Indian Journal of Dairy Science 56 235-240.

Khatun M, Sørensen P, Jørgensen HB, Sahana G, Sørensen LP, Lund MS, Ingvartsen KL, Buitenhuis AJ, Vilkki J, Bjerring M, Thomasen JR, Røntved CM 2013: Effects of Bos taurus autosome 9-located quantitative trait loci haplotypes on the disease phenotypes of dairy cows with experimentally induced Escherichia coli mastitis. Journal of Dairy Science 96 1820-1833

Kivaria FM, Noordhuizen JPTM, Kapaga AM 2004: Risk factors associated with subclinical mastitis in small holder dairy cows in Tanzania. Tropical Animal Health and Production 36 581-592.

Minozzi G, Nicolazzi EL, Strozzi F, Stella A, Negrini R, Ajmone-Marsan P, Williams JL 2011: Genome wide scan for somatic cell counts in Holstein bulls. Bio Medical Center Proceeding 4 S17.

Mungube EO, tenhagen BA, Kassa T, Regassa F, Kyule MN, Greiner M, Baumann MPO 2004: Risk factors for dairy cow mastitis in the central highlands of Ethiopia. Tropical Animal Health and Production 36 463-472. 
Murphy K, Travers P, Walport M 2008: Innate immunity in immune biology, $7^{\text {th }}$ edn. Garland Science, Taylor \& Francis Group, LLC.

Nooruddin M, Ali LM, Debnath NC 1997: Retrospective epidemiologic study of periparturient diseases in dairy cows. The Bangladesh Veterinarian 14 43-47.

Pankey JW, Drechsler PA, Wilkman EE 1991: Mastitis prevalence in primigravid heifers at parturition. Journal of Dairy Sciences 74 1550-1552.

Pighetti GM, Elliott AA 2011: Gene polymorphisms: the keys for marker assisted selection and unravelling core regulatory pathways for mastitis resistance. Journal of Mammary Gland Biology and Neoplasia 16 421-432.

Radostits OM, Gay CC, Blood DC, Hinchliff KW 2000: Mastitis. In Veterinary Medicine, A text book of the diseases of cattle, sheep, pigs, goats and horses. $9^{\text {th }}$ edn. WB Saunders Co. Philadelphia, pp. 603-612.

Romain HT, Adesiyun AA, Webb LA, Lauckner FB 2000: Study on risk factors and their association with sub-clinical mastitis in lactating dairy cows in Trinidad. Journal of Veterinary Medicine 47 257-272.

Rasmussen DB, Fogsgaard K, Røntved CM, Klaas IC, Herskin MS 2011: Changes in thermal nociceptive responses in dairy cows following experimentally induced Escherichia coli mastitis. Acta Veterinaria Scandinavica 5332.

Rosenberger G 1979: Clinical examination of cattle. 1'st edn, Verlag, Paul Parey, Brelin, Germany, pp. 215-220.

Sarkar SC, Parvin MS, Rahman AK, Islam MT 2013: Prevalance and risk factors of subclinical mastitis in lactating dairy cows in north and south regions of Bangladesh. Tropical Animal Health and Production 45 1171-1176

Shem MN, Malole JML, Machangu R, Kurwijila LR, Fujihara T 2001: Incidence and causes of subclinical mastitis in dairy cows on small holder and large scale farms in tropical areas of Tanzania. Asian-Australasian Journal of Animal Sciences 14 372-377. 